Katarzyna Ornacka ำ http://orcid.org/0000-0002-9305-8476

Marta Kamińska ำ http://orcid.org/0000-0001-7553-9826

Uniwersytet Jagielloński

Elżbieta Mirewska inttp://orcid.org/0000-0003-3857-343X

Uniwersytet Pedagogiczny w Krakowie

\title{
O ZRANIONYCH TOŻSAMOŚCIACH I ROZPOZNAWANIU PRZEMOCY WOBEC DZIECI
}

\section{Abstract \\ On vulnerable identities and recognition of child abuse}

The phenomenon of violence against children is a serious social problem, and public awareness about the effects of violence for children remains at a low level. Children with vulnerable identity experience a developmental trauma that has a negative impact on the child's development as well as on the functioning of adult life. Children who are abused with even more determination must fight for attention, recognition, dignity and, above all, for the right to be themselves. The issue of violence against children raises questions about who and how does it deal with the protection of victims of violence and the promotion of human rights, especially children's rights? In what direction should social education develop so that the legal regulations are consistent with the knowledge and skills necessary to understand the child's situation and initiate appropriate assistance activities? What can adults learn from children? Answers to the above questions were given by a person who, through his activities in the "Ad Vocem" Foundation, works with (abused) people every day and who believes that listening to the voice of children is a way to understand what is important to them and what they need. Because - as she claims - knowledge and skills give a sense of security and courage for effective action.

Key words: vulnerable identity, social work, child abuse

Dziecko chce być dobre. Jeśli nie umie - naucz, jeśli nie wie - wytłumacz, jeśli nie może - pomóż! [...] Jeśli nie potrafię dziecka wychować łagodnym słowem,

spojrzeniem i uśmiechem - zawiedzie i ręka, i pas, chociażbym nie żałował.

Janusz Korczak (2002)

Naszą rozmówczynią była Anna Grajcarek - ekspertka ds. walki z przemocą wobec dzieci, ochrony praw człowieka, szczególnie ofiar przestępstw. Założycielka i prezes fundacji „Ad Vocem", autorka bestsellerów: Sztuka rozmowy z chorym, Gdy dziecko potrzebuje pomocy (książka przygotowana na zamówienie ONZ) oraz Jak rozpoznać dziecko krzywdzone. 
Od 1992 roku współpracuje z Organizacją Narodów Zjednoczonych, przede wszystkim z jej dwoma agendami UNFPA i UNDP. Fundacja „Ad Vocem” - będąca polem działania społecznego Anny Grajcarek - rozpoczęła swoją działalność w 2005 roku. Jej głównym celem jest promowanie praw człowieka, w tym przede wszystkim praw dzieci i praw ofiar przestępstw. Fundacja prowadzi też interwencje w przypadku, gdy zawodzi system prawny. Skupia osoby pragnące pomagać pokrzywdzonym bronić swoich praw, zwłaszcza dzieciom. Fundacja „Ad Vocem” pracuje głównie w ramach wolontariatu. Z fundacją współpracują specjaliści z dziedziny psychologii, medycyny, prawa, osoby cieszące się szacunkiem w swoim środowisku zawodowym (http://advocem.org.pl/).

\section{Rozmowa}

Jest Pani osoba nietuzinkowa, bardzo pracowita, podejmująca coraz to nowe wyzwania, ciagle w biegu, a przy tym szalenie spokojna i skromna. W jakim stopniu te cechy - skromność i pokora - pomagaja, a w jakim utrudniaja działania, które Pani podejmuje?

To, że jestem takim zwyczajnym człowiekiem, pewnie wzięło się z mojego dzieciństwa. To było bardzo zwyczajne dzieciństwo. Wychowywały nas - mnie i dwójkę moich braci - dwie kobiety: mama i babcia. Ważne jest to, że w tym wczesnym dzieciństwie wychowywaliśmy się w głębi lasu. W jego okolicy były jedynie łąki. - Nasz dom był usytuowany z dala od ludzi. Żyliśmy bardzo skromnie, ale moja mamuńcia [podkr. A.G.] była czarodziejką, ponieważ potrafiła szyć i wyczarowywała dla nas piękne ubranka. Była wspaniałą osobą, która wnosiła do naszego trudnego życia spokój i bezpieczeństwo. Muszę dodać, że mieszkaliśmy w okolicach Bielska. Było to takie miejsce, z którego ogromną liczbę mieszkańców wysyłano do Niemiec do pracy. W czasie wojny, kiedy moja mama była jeszcze dzieckiem, moi dziadkowie w obawie przed tym, żeby ich córka nie została wysiedlona do Niemiec do pracy, wysłali ją do szkoły podstawowej sióstr w Straconce - sióstr czarodziejek, które uczyły gotowania, pieczenia, haftowania, robienia na drutach oraz szydełkowania. Dzięki nim moja mamuńcia była bardzo samodzielna $\mathrm{i}$ - jak powiedziałam - potrafiła wyczarować COŚ z niczego.

Nasz ojciec, był człowiekiem bardzo poranionym przez wojnę - zdał maturę w 1939 roku i jako nadający się do pracy młody mężczyzna, pierwszym transportem trafił do Niemiec. Nie skarżył się, chociaż było trudno. Przeżył piekło, które pozostawiło w nim ślady do końca życia. Jego wędrówka przez Niemcy szlakiem Armii Czerwonej aż do Czerwonego Krzyża po to, żeby zostać ewakuowanym do Polski, była pełna dramatycznych przeżyć i obrazów. To, co zobaczył wraz z innymi, którzy mu towarzyszyli, sprawiło, że po powrocie do domu nie mógł się już odnaleźć. Był „nieobecny” i nieprzystosowany do życia w rodzinie, do bycia ojcem. Jego doświadczenia i jego historia bardzo mocno wpłynęly na nasze życie, ponieważ mieliśmy ojca, który był „obok nas” i z którym nie mieliśmy kontaktu. 
A kiedy się Pani o tym dowiedziała? Kiedy była Pani mała dziewczynka?

Nie rozmawialiśmy na temat tego, co robił [tata] w czasie wojny, czego doświadczył i co spowodowało, że był taki nieprzystosowany. Dopiero jako nastolatka, a właściwie już jako osoba dorosła, próbowałam dochodzić do tego, jak to się stało, i zaczynałam rozumieć zachowanie mojego taty.

Czy to miało wpływ na Pani decyzję o tym, że została Pani pielegniarka?

Raczej nie, ponieważ zawsze bardzo chciałam być pielęgniarką. Żyłam w takim rejonie Polski, w okolicach Bielska, gdzie oznaką statusu było to, że chłopiec zostaje księdzem, a dziewczynka pielęgniarką. Takie było moje pierwsze marzenie. Nie ukrywam, że moja babcia bardzo mi to odradzała - uważała, że to jest bardzo trudny zawód i chciała mi tego trudu oszczędzić. Nie przeczę, że rzeczywiście jest to trudne - po szkole pielęgniarskiej trafiłam na Akademię Medyczną, zdawałam na Wydział Lekarski, ale przyjęli mnie na farmację, ponieważ zabrakło mi kilku punktów. Byłam kilka semestrów na farmacji i okazało się, że to nie to, chociaż dobrze to wspominam, (...) ale życie akademickie było takie ciekawe. Ja nie chodziłam na zabawy, natomiast byłam na wszystkich koncertach, które w tym czasie odbywały się w Krakowie - w akademiku przy ul. Grzegórzeckiej 20. Wszyscy, którzy się wtedy liczyli - m.in. Maryla Rodowicz, „Czerwone Gitary”, Święcicki - tam koncertowali. Potem trafiłam na praktyki studenckie i do szpitala uniwersyteckiego Akademii Medycznej na oddział hematologii, no i już zostałam. To było coś takiego, co rzeczywiście zmieniło moje życie - zobaczyłam oddział inny, niż miałam wyobrażenie z moich praktyk, i ponownie zostałam pielęgniarką. Niestety nie trwało to długo, ponieważ zaraziłam się żółtaczką i byłam zmuszona zmienić miejsce pracy. Zostałam przeniesiona z oddziału na salę operacyjną. I wtedy zrozumiałam, że nieoczekiwanie spełniło się moje marzenie.

Pani aktywność i zaangażowanie bardziej skupiały się na dorostych, prawda? Kiedy zaczęła się Pani interesować problematyka dzieci?

Rzeczywiście, do pewnego momentu żyłam w takiej enklawie, jaką była sala operacyjna. To takie miejsce szczególne - pacjenci trafiają na stół operacyjny, a potem wyjeżdżają na oddział. Kiedy pojawia się u nich lęk, można z nimi tylko porozmawiać, ale to jest jakby dorosły świat.

Moje życie zmieniło się wówczas, gdy zostałam przewodniczącą samorządu i kiedy zaczęły się problemy w szkołach, z których usunięto lekarzy i zostawiono jedynie pielęgniarki. Trudność polegała na tym, że dotychczas pielęgniarki ściśle współpracowały z lekarzami, udzielały im wsparcia i mogły na podobne wsparcie liczyć. A tymczasem zostały same i powierzono im zadanie, do którego były kompletnie nieprzygotowane. Znalazły się w trudnej sytuacji i pojawiły się problemy, którymi na szczęście dzieliły się ze mną. Dotyczyły one trudności dnia codziennego oraz uczniów. Opowiadały o dzieciach wykorzystywanych, maltretowanych, o takich, które znalazły się w dziecięcym piekle. Ja sobie w ogóle nie zdawałam z tego sprawy. Od czasu do czasu pojawiały się w prasie jakieś 
artykuły, słyszeliśmy o przypadkach dzieciobójstwa, ale ja nie wiedziałam, że skala tego zjawiska jest tak duża i nikt z tym nic nie robi! Myślałam, że jakoś to jest uregulowane.

Zorganizowałam spotkanie dla grupy pielęgniarek szkolnych i wysłuchałam ich historii. Nie ukrywam, że dużo mnie to kosztowało - nie spałam kilka nocy - ponieważ historie były niewiarygodne, trudne do wyobrażenia. To spotkanie było dla wszystkich uczestników bardzo ważne - byliśmy mocno zmotywowani do działania i zmiany, gdyż uznaliśmy, że nie zgadzamy się z taką sytuacją, z takim stanem rzeczy. Postanowiliśmy, że przygotujemy pielęgniarki do pracy z dziećmi, a tym samym zwiększymy im zakres odpowiedzialności za swoją pracę (żeby miały poczucie sensu i uznania). Od tego momentu moja aktywność skupiona była przede wszystkim na rozpoznawaniu możliwości i zakresu wsparcia ze strony urzędujących wówczas ministrów. Jak się okazało, środowisko osób, które znałam, nie chciało słuchać moich propozycji, dlatego moje działania były trudne i przez jakiś czas bezskuteczne. Aż pewnego dnia jeden z moich znajomych opowiedział mi o kobiecie, która była związana z Organizacją Narodów Zjednoczonych - zajmowała wysokie stanowisko w tej organizacji i miała świetne kontakty - i zachęcił do tego, żebym się z nią skontaktowała. Faktycznie, zrobiłam to i muszę przyznać, że był to początek dobrego okresu w moim życiu, ponieważ w ten sposób rozpoczęłam współpracę, która trwa do dzisiaj. Przygotowałam mój pierwszy projekt, który spodobał się, został przyjęty i otrzymaliśmy sporo pieniędzy na jego realizację.

\section{Który to był rok?}

To był 1991 rok, a projekt realizowaliśmy w 1992 roku. Jednak wcześniej przygotowaliśmy projekt, który dotyczył kobiet w ciąży, które były zakażone HIV albo chorowały na AIDS i trafiały na oddział położniczy (tzw. porodówkę), z którego wszyscy lekarze uciekali. Zostawały jedynie pielęgniarki, ponieważ one były przygotowane do pracy $\mathrm{z}$ chorymi. One też się bały, nikt nie uczył, jak uchronić się przed tymi chorobami, ale zostawały z pacjentkami. Mój kolega minister powiedział, że to jest sprawa zboczeńców, a nie normalnych ludzi, więc co on będzie sobie głowę zawracał. Wtedy już wiedziałam, że potrzebny jest poradnik! Miałam doświadczenie, jak to zrobić, z mojej wcześniejszej działalności, więc ani przez chwilę się nie zastanawiałam. Wydaliśmy więc superporadnik, który - jestem z tego strasznie dumna - jako jedyny miał cztery wydania i „wyszedł” w nakładzie 116 tysięcy egzemplarzy. W każdej, nawet najmniejszej poradni, przychodni była dostępna wiedza o tym, jak się ustrzec HIV i AIDS, czyli informacje dla pracowników ochrony zdrowia - i to był pierwszy projekt, mieliśmy dobre wejście. Mój drugi projekt - szkolenie stugodzinne, był już bardziej skomplikowany. Przygotowywaliśmy go w latach 1993-1994, kiedy wchodził w życie Narodowy Fundusz Zdrowia, wspólnie ze współpracownikami z ONZ. Został on zaakceptowany. Przeszkoliliśmy 711 pielęgniarek pracujących z dziećmi z całej Małopolski. Osoby te „pochodziły” ze szpitali, szkół i placówek opiekuńczo-wychowawczych. Otrzymały od nas taki duży poszerzony warsztat oraz wiedzę, którą mogły wykorzystać w swojej pracy. Dodatkowo powstała publikacja.

W mojej działalności edukacyjnej i projektowej cały czas miałam wsparcie ze strony dwóch agend: UNDP w ramach Programu Narodów Zjednoczonych ds. Rozwoju oraz 
UNPFA w ramach Programu Ludnościowego. Zresztą to wsparcie otrzymuję do dzisiaj. Było to dla mnie bardzo ważne, ponieważ zawsze uczono mnie, że aby dobrze wywiązywać się ze swoich obowiązków, ludzie zawsze muszą być przygotowani, a otrzymaną wiedzę trzeba utrwalać, ponieważ za chwilę uleci, czyli konieczny jest poradnik. Tak właśnie robiliśmy - realizowaliśmy projekt, a potem powstawała książka. Zwykle ja ją wymyślałam i zapraszałam różnych autorów, żeby pisali o rzeczach, na których ja się nie znałam, bo przecież nie znam się na wszystkim, i tak powstawały te książki...

\section{Czy już wtedy była fundacja?}

Fundacja pojawiła się nieco później, wcześniej jeszcze taką bazą był samorząd, była korporacja i zajmowaliśmy się różnymi rzeczami: powstawały publikacje czy programy. Nasza działalność związana była „z potrzebą chwili”. Gdy zmieniało się prawo, pracowaliśmy nad jego udoskonaleniem. Podam przykład, przez wiele lat informowanie pacjentów o wykonywanych wobec nich czynnościach w związku z chorobą należało do lekarzy i było dla nich zarezerwowane. Przepisy prawa nie regulowały tych kwestii wobec pielęgniarek oraz pozostałych osób z personelu zajmujących się chorymi. Powiem więcej, nikogo nie uczono, jak rozmawiać z chorym, zamiast tego powtarzano pielęgniarkom, że to nie ich problem i że „wchodzą na cudze pole”. Sytuacja zmieniła się, kiedy zostałam przewodniczącą Komisji Prawa i Legislacji Naczelnej Rady Pielęgniarek i Położnych. Moje zaangażowanie i determinacja osób, z którymi współpracowałam, przyczyniły się do zmian w prawie. W nowej ustawie o prawach pacjenta pojawił się zapis, zgodnie z którym pielęgniarki miały obowiązek przeprowadzania rozmowy z pacjentami. Dodam jeszcze, że w tym trudnym okresie bardzo pomógł mi ksiądz prof. Józef Tischner, który powtarzał, że trzeba rozmawiać z chorymi. Ta myśl Profesora była dla mnie inspiracją do przygotowania książki pod tytułem Sztuka rozmowy z chorym - projekt, do którego zaprosiłam znakomite autorytety.

\section{Czy na swojej drodze napotykała Pani dużo trudności i jak sobie Pani z nimi radziła?}

Tak, bardzo dużo, naliczyłam do dzisiaj dziewiętnaście pozwów i tyle samo aktów oskarżenia. Zauważyłam, że nasze działania edukacyjne dotyczące podnoszenia umiejętności radzenia sobie w sytuacjach trudnych, skierowane do 711 pielęgniarek pracujących z dziećmi, są niewystarczające. Postanowiliśmy uczyć również nauczycieli, psychologów i pedagogów. Największym wyzwaniem dla nas okazało się jednak środowisko lokalne, w którym świadomość zagrożenia ze strony sprawców przemocy oraz umiejętność wspierania ofiar były bardzo niskie. Ta sytuacja skłoniła nas do podjęcia kolejnych działań skoncentrowanych na zapewnieniu wsparcia pielęgniarkom, które znajdowały się pomiędzy tym środowiskiem i dziećmi i były najbardziej narażone na kontakt z agresywnymi osobami. Uznaliśmy, że jeśli nie zapewnimy pielęgniarkom poczucia bezpieczeństwa w pracy, wówczas ich poziom zaangażowania spadnie, stracą motywację, wskutek czego największe koszty poniosą najmłodsi.

Odpowiedzią na nasze problemy i trudności była fundacja, którą założyliśmy 17 maja 2005 roku. Fundacja interweniuje w każdym przypadku, kiedy system zawodzi dziecko 
krzywdzone, zajmuje się promowaniem praw ofiar przestępstw, praw człowieka, ale przede wszystkim dzieci. Nie pomagamy natomiast finansowo, nie zbieramy pieniędzy, tylko zajmujemy się stroną merytoryczną. Do nas mogą zwracać się osoby po pomoc prawną (mamy prawników), ale także ci, których spotykają represje z tego powodu, że się zachowali przyzwoicie. W takiej sytuacji fundacja przejmuje sprawę, jest stroną. Nasza praca polega na tym, że chodzimy do sądu, czytamy akta i świadczymy konkretną pomoc. Muszę powiedzieć, że ta pomoc jest bardzo potrzebna, ponieważ oprawcy zwłaszcza tacy, którzy stosują przemoc seksualną oraz podejrzani o pedofilię - są bardzo agresywni. Poza tym, o czym już wspominałam, udzielamy pomocy prawnej, ponieważ niektóre z uregulowań prawnych są przygotowywane niezwykle niedbale. Czy trzeba dużej wyobraźni, żeby przewidzieć, co się stanie, gdy oprawca nie jest współwłaścicielem, tylko właścicielem? Wystarczyłoby, aby w tym czasie, kiedy jest przymusowa eksmisja, nie miał on prawa zarządzać tym majątkiem. Inaczej, skutek jest taki, że kobiety wycofują sprawę, bo wolą być maltretowane, niż bez dachu nad głową.

\section{A jaka jest skala tego zjawiska?}

Muszę powiedzieć, że skala jest bardzo tajemnicza, kompletnie nie do określenia - bo ani statystyki policyjne tego nie oddają (nie wszystko trafia na policję), ani też badania szacunkowe. Tutaj ta szara strefa jest bardzo tajemnicza i im okrutniejsze zbrodnie wobec dzieci, tym bardziej to jest tajemnicze.

Rzecz w tym, że na etapie przygotowywania zmian w prawie zaangażowane były osoby niekompetentne. Na przykład już w połowie lat dziewięćdziesiątych XX wieku Państwowy Instytut Higieny miał prowadzić statystyki maltretowania dzieci przez dorosłych oraz maltretowanych dzieci zdiagnozowanych w szpitalu. W rzeczywistości gdy dziecko trafia do szpitala, nie zawsze jest diagnozowane, ponieważ często matka mówi, że spadło ze schodów. W takiej sytuacji nie wykonuje się dodatkowych badań. Dobrze jednak wiemy - po czynach dzieciobójczych - że tylko nieliczni trafiają do szpitala. W rezultacie te podejmowane działania są jedynie działaniami pozornymi. Podam jeszcze inny, bardziej kuriozalny przykład - przeglądając różne statystyki, znalazłam takie, które podają liczbę osób okaleczonych w wyniku wypadków z „udziałem” kosiarki, natomiast mało kto interesuje się dzieckiem maltretowanym, zabitym czy skatowanym. To już nie stanowi problemu. Prawdopodobnie nikt nie liczy tych dzieci. Oczywiście, my się nie poddajemy i próbujemy namawiać różnych ludzi i instytucje do przygotowywania statystyk, które uwzględniałyby liczbę dzieci trwale okaleczonych, $\mathrm{z}$ trwałym niedorozwojem umysłowym na skutek przemocy w dzieciństwie albo w wyniku nadużywania alkoholu przez matki w czasie ciąży. Dobrze wiemy, że każda ilość alkoholu ma wpływ na dziecko. W naszych rozmowach z kobietami w ciąży pytamy, czy lekarz informował pacjentki o zagrożeniach związanych z nadużywaniem alkoholu w ciąży, ale niestety $\mathrm{z}$ tych wizyt i rozmów $\mathrm{z}$ lekarzem nic nie wynika. W praktyce oznacza to, że gdy zdiagnozujemy dziecko z zespołem alkoholowym, matka musi wyrazić zgodę na badanie i leczenie. Czy zatem kobieta, będąc w ciąży, przyzna się do picia alkoholu? Raczej nie, i koło się zamyka. 
Jak Pani sądzi, skąd ten opór wobec zmiany?

Opór jest dlatego, że tak jest wygodniej. Patrzeć z boku, nie wiedzieć. Dodatkowo, taką postawę usprawiedliwia się tym, że wtrącać się „nie jest trendy”. Pora zatem na zmianę mentalności.

\section{W jaki sposób będzie Pani wprowadzać zmiany w ludziach?}

Wprowadzamy zmiany dwutorowo: poprzez edukację społeczną oraz poprzez zabezpieczenie prawne świadków ofiar przemocy. Mamy świadomość, że uregulowania prawne muszą iść w parze z edukacją. Weźmy na przykład ustawę o przeciwdziałaniu przemocy w rodzinie. Jeżeli kurator powiatowy nie wie, że do jego obowiązków należy podejmowanie różnych działań oraz że jeśli jego podwładni nie wykonają konkretnych poleceń, wówczas będą mieli poważne problemy, to znaczy, że jest to słabość, luka w systemie i należy ją wypełnić wiedzą. Innym przykładem jest ustawa o ochronie praw świadków i ofiar. Została ona dobrze przygotowana, ale ludzie, którzy powinni z niej korzystać, muszą o niej wiedzieć i rozumieć zawarte w niej zapisy. Tymczasem ich poziom wiedzy jest niski.

Zdajemy sobie sprawę, że musimy zmieniać mentalność ludzi. Poprzez projekty poszukujemy nowych ludzi, którzy mogliby nam pomóc wprowadzać te zmiany. Dotarliśmy do kurii i nawiązaliśmy współpracę z pewnym księdzem. Chcielibyśmy nawiązać kontakt z seminariami, gdyż wiemy, że jeżeli duchowni zaapelują do ludzi, to oni posłuchają. Z doświadczenia wiem, że tego rodzaju przekaz jest bardziej skuteczny niż zachęcanie ludzi do zmiany za pośrednictwem publikacji, pisemnych apeli czy spotkań ze zwykłymi obywatelami. Od kilku lat działamy więc pod szyldem „Jedenaste nie bądź obojętny" - i tak też nazwaliśmy tę część naszego projektu.

Jednocześnie mamy świadomość, że system prawny nie gwarantuje pełnej ochrony świadkom przemocy. W praktyce daje większą ochronę sprawcom tej przemocy. I najtrudniejsze do zaakceptowania przeze mnie i przez ludzi, z którymi współpracuję, jest to, że ustawodawca powołuje się na działania w zgodzie z prawami człowieka. Takie podejście jest dla mnie niezrozumiałe. Przez kilkadziesiąt lat byłam zaangażowana w obronę praw człowieka, chciałam, aby były one przestrzegane, zwłaszcza w stosunku do dzieci. Dlatego też podejmujemy kolejne działania ukierunkowane na weryfikację ustawy o ochronie danych osobowych. Rozmawiamy z Rzecznikiem Praw Obywatelskich, Rzecznikiem Praw Dziecka. Zdajemy sobie sprawę, że ich działania są ograniczone przepisami i nie mogą nam pomóc w wystarczający sposób.

Słyszymy od wielu osób, że ta ustawa jest podobna pod wieloma względami do tych obowiązujących w innych krajach, m.in. skandynawskich. Społeczeństwo skandynawskie jest jednak na innym poziomie rozwoju społecznego w porównaniu z naszym społeczeństwem, dlatego musimy zrobić wszystko, aby w większym zakresie chronić interesy dzieci, ofiar przestępstw. Czasami towarzyszymy naszym podopiecznym w sądach. Współpracujemy też z sędziami, którzy mają w sobie empatię i okazują ją w kontaktach z dziećmi. Jednak błędy i wypaczenia zdarzają się zbyt często, więc nasze działania są potrzebne. 
Dysponujemy danymi z policji, z których wynika, że ponad 70\% skarg związanych z Niebieską Kartą jest umarzanych, a z tych 70\% do ukarania dochodzi w około 2-3\% przypadków. Przykłady można by mnożyć - pomagają nam w tym dziennikarze. I tak za zabójstwo dorosłego człowieka mamy karę dożywocia lub 25 lat więzienia, a za zabójstwo dziecka - 5 lat, za gwałt ze szczególnym okrucieństwem na dwuletniej dziewczynce okaleczonej już na całe życie, której z trudem lekarze uratowali życie, oprawca dostaje 5 lat! Za gwałt ze szczególnym okrucieństwem na dziewczynie szesnastoletniej - 2 lata w zawieszeniu. Na przykład w Belgii za zgwałcenie dziecka w wieku poniżej 10 lat grozi kara od 20 do 30 lat więzienia, a we Francji grozi kara 20 lat więzienia za zgwałcenie dziecka w wieku poniżej 15 lat. W Polsce jest inaczej. My nie zgadzamy się z tym i próbujemy zmienić tę sytuację.

Wszyscy mają prawa, wszyscy są równi! Jednak dzieci są po prostu traktowane gorzej! Żeby zmienić tę sytuację, konieczne są działania edukacyjne - ludzie potrzebują wiedzy, w jaki sposób postępować. Według mnie inwestycja w człowieka to najlepsza inwestycja. Współpracujemy z wieloma osobami, w kraju i za granicą, i wiemy, że inne kraje rozwiązały problemy, z którymi my się borykamy. Możemy korzystać z ich doświadczeń, nie musimy popełniać podobnych błędów. Jesteśmy gotowi do podjęcia działań, ta zmiana ma jednak charakter systemowy i wymaga współpracy na wielu poziomach. Trudność polega na tym, że system sprawiedliwości nie zawsze jest po naszej stronie, czyli po stronie dziecka. Chociaż nasza praca wiąże się z codziennym pokonywaniem trudności, to jesteśmy zdeterminowani i będziemy kontynuować naszą misję. Taką nadzieję dają nam na przykład sądy apelacyjne i sprawowany nad nimi nadzór administracyjny - dzięki niemu i zaangażowanym pracownikom możemy przyspieszyć procedowanie sądu w konkretnych sprawach.

Czy udało się Pani powtórzyć badania z pielegniarkami zatrudnionymi w szkołach, które miały bezpośredni kontakt $z$ dziećmi? Co się zmieniło?

Chodzi o te badania dotyczące akceptacji przemocy? Tak, przeprowadziliśmy badania dwukrotnie: za pierwszym razem grupa respondentów liczyła 700 dzieci, za drugim już 2300 osób. Nie planowaliśmy badań porównawczych, ponieważ naszym celem było zaistnienie w środowisku dzieci, a następnie przygotowanie projektu, który umożliwiłby dzieciom zdobycie umiejętności radzenia sobie z emocjami. Uważaliśmy, że dopiero na kolejnym etapie badanie dynamiki i kierunku zmiany miałoby sens dla nas i osób pracujących z dziećmi. W przeciwnym razie trudno byłoby stwierdzić, jaki był nasz wpływ na jakąkolwiek zmianę, którą mogliśmy zaobserwować w środowisku.

$\mathrm{Z}$ myślą o naszej grupie docelowej, którą stanowią dzieci, przygotowywaliśmy kolejne projekty. Okazało się jednak, że dotychczas nie wzbudziły one większego zainteresowania wśród grantodawców. $Z$ doświadczenia wiem, że dzieci nie są traktowane poważnie. Obecnie planujemy rozpocząć współpracę z osobami z Komisji ds. Rodziny przy Sejmiku Wojewódzkim. Naszym partnerem jest Urząd Miasta - Wydział Spraw Społecznych - bardzo życzliwi ludzie, którzy wspierają nas nie tylko merytorycznie, lecz także finansowo, wynajmując nam sale multimedialne, co znacznie obniża koszty. 
Ponadto znajdujemy zaangażowanych ludzi, którzy są otwarci na zmianę. Liczymy, że $\mathrm{z}$ ich pomocą będziemy w stanie przygotować projekt, dzięki któremu bardziej zbliżymy się do dzieci.

Czy spotkała się Pani z takim określeniem dzieci o zranionej tożsamości, które jednocześnie musza walczyć o uznanie, o miłość, o godność, o prawo do bycia osobą?

Tak, spotkałam się z takimi dziećmi, najczęściej z tymi, które do nas trafiają, a nie jest ich zbyt wiele, ponieważ to jest wierzchołek góry lodowej. To są dzieci pokrzywdzone z powodu ubóstwa, np. matka niezaradna pod względem ekonomicznym, ale dobrze radząca sobie w realizacji funkcji opiekuńczej i wychowawczej; dwunastoletnia dziewczynka, która nie chodzi do szkoły, ponieważ jej sytuacja materialna nie pozwala na noszenie modnych strojów, a rówieśnicy się z niej śmieją. Pytam kiedyś piętnastoletnią dziewczynkę, o czym marzy, a ona mi mówi tak: marzę o tym, aby codziennie przez cały tydzień zakładać sobie inne kolczyki. Takie marzenia mają dzieci z biedy - to znaczy $z$ rodzin, które mają niski status materialny. Są również dzieci opuszczone i zaniedbane przez dorosłych - pochodzą z dobrze sytuowanych rodzin, mogą zaspokajać swoje potrzeby bez ograniczeń, a w kontaktach z innymi zachowują się agresywnie i arogancko. Wydaje mi się, że chcą w ten sposób zwrócić na siebie uwagę rodziców, chcą im powiedzieć „jestem w tej rodzinie, zauważcie mnie”, ale często nie otrzymują ich uwagi. Pewnie kiedy dorosną będą zachowywały się inaczej, najbardziej bolesne tu i teraz jest jednak to ich szydzenie $\mathrm{z}$ biedy! W jednych i drugich rodziny dzieci muszą walczyć o siebie, o uznanie i miłość, a to wpływa na ich rozwój oraz kształtowanie ich tożsamości.

Czy myśli Pani, że dziecko można traktować jak partnera, bardziej podmiotowo? Jeśli tak, to jakiego typu może to być partnerstwo?

Wydaje mi się, że trudno o partnerstwo między dzieckiem i dorosłym. To są dwa różne światy. Podam przykład moich relacji z rodzicami - z moją mamą i babcią. One nie były moimi partnerami czy koleżankami, one były dla mnie wzorem do naśladowania, autorytetem. Wydaje mi się, że rodzic autorytet to taka osoba, która zapewnia dziecku bezpieczeństwo. Dziecko ma się czuć bezpiecznie. Według mnie dzieci szukają wzorców, a nie koleżanek. Poza tym w rodzinie potrzebny jest autorytet, czyli ktoś, komu należy się szacunek - kolegów też szanujemy, ale szacunek wobec rodziców ma nieco inny charakter i znaczenie. Wydaje mi się, że jesteśmy zaprogramowani genetycznie w taki sposób, że starszy członek rodziny ma wspierać młodszych. To wsparcie wiąże się z tym, że posiada on większe doświadczenie i wiedzę, które dla młodszych są drogowskazem i z których w atmosferze zaufania i poczucia bezpieczeństwa mogą oni korzystać. Moim zdaniem takie bratanie się, które było powszechne w latach sześćdziesiątych XX wieku, przyniosło więcej szkody aniżeli korzyści. Kilka lat temu miałam okazję przeczytać pamiętniki „dzieci kwiatów” - historie w nich opisane potwierdzają moje przypuszczenia, że dzieci w tym czasie były krzywdzone i do świata dorosłych weszły już okaleczone. 
Czy myśli Pani, że dorośli moga się czegoś od dzieci nauczyć? Czy zgadza się Pani z teza, $\dot{z}$ e dziecko jest kompetentnym aktorem?

Dziecko dopóki nie utraci niewinności jest autentyczne. Wraz z wiekiem zaczyna grać, dostrzega, jakie zachowania mu się opłacają, a jakie nie. I wtedy już nie jest autentyczne, staje się aktorem. Nie jest jednak powiedziane, że tę niewinność musi utracić, jak ma sześć lat czy dziesięć. Można być nastolatkiem albo dorosłym człowiekiem i zachować niewinność. Natomiast tym, czego od dzieci można się nauczyć, jest - według mnie szczerość i autentyczność połączona ze spontanicznością.

Na przykład, w jednym z prowadzonych przez nas badań okazało się, że nastolatkowie mają problem z odróżnieniem maltretowania od „Zwykłych” kar¹. Zapytaliśmy dzieci w wieku 7-15 lat, kiedy mamy do czynienia z maltretowaniem, a kiedy ze zwykłą karą, i okazało się, że młodsze dzieci (7-10 lat) udzieliły odpowiedzi, natomiast starsze (11-15 lat) miały trudności z odpowiedzią. Ponad $90 \%$ badanych jednoznacznie odpowiedziało, że maltretowanie jest wtedy, gdy po biciu są ślady. Jest w tym jakaś prawda. Mówimy, że dziecko jest krzywdzone wtedy, gdy zostało ukarane i są ślady. Myślę więc, że można by dzieci jeszcze o wiele rzeczy zapytać, dzieci mogą dać jakieś wskazówki, a najważniejsze jest to, że mogą powiedzieć, co jest dla nich ważne, jeszcze bez tego udawania i zastanawiania się, co im się bardziej opłaci.

Nasze badania wiele wnoszą, a $\mathrm{z}$ ankiet możemy dużo wyczytać. Zawdzięczamy to współpracy z naszą psycholog kliniczną. Pytamy na przykład: widzisz na ulicy, że dorosły bije dziecko, co o tym myślisz? W odpowiedzi czytamy lub słyszymy: no, ma przechlapane, coś zrobił. A jak na ulicy twojego kolegę bije tata, co o tym myślisz? W tym przypadku odpowiedź nie była już taka jednoznaczna. Oczywiście tego typu pytania zadajemy mniejszym dzieciom, to znaczy do ósmego lub dziewiątego roku życia, ale one pokazują specyficzny sposób myślenia. Podobnego sposobu myślenia już przy starszych dzieciach nie było. One mówiły: „no nie wypada”, i koniec. Wniosek jest taki, że jednak się różnimy, chociaż nasze badania „pokazały” również, że myślimy bardzo stereotypowo.

Zauważyliśmy na przykład, że bastionem kar cielesnych nie jest już wieś. Zaczęliśmy się zastanawiać, co się stało i dlaczego tak się stało. I okazało się, że jednym z powodów jest to, że na wsi są w dalszym ciągu rodziny wielopokoleniowe, czyli są babcia i dziadek, którzy chronią dzieci przed przemocą. To najstarsi członkowie rodziny są takim buforem, który zabezpiecza najmłodszych, natomiast w mieście tego nie ma (albo bardzo trudno go znaleźć). Ponadto zauważyliśmy że dzieci, które w ogóle nie doznały i nie stosują agresji, akceptują agresję - młodsze dzieci, natomiast te, wobec których stosowano przemoc (jak wynikało z ankiet) i są krzywdzone, nie są specjalnie agresywne... Oznacza

1 Kara fizyczna (kara cielesna) to każda kara, do której wymierzenia używana jest siła fizyczna i która w zamierzeniu ma sprawić ból lub dyskomfort (Eliminating Corporal Punishment... 2005). Natomiast maltretowanie dziecka to wszystkie formy fizycznego i/lub emocjonalnego złego traktowania, zaniedbania, wykorzystania seksualnego lub komercyjnego, doznane od osoby odpowiedzialnej za dziecko, której ono ufa lub która ma nad nim władzę, skutkujące faktyczną lub potencjalną krzywdą dziecka dla jego zdrowia, możliwości przetrwania, rozwoju albo godności (Report of the Consultation on Child Abuse Prevention 1999) [przyp. aut.]. 
to, że ci, którzy doznawali krzywdy, mniej chętnie rozstrzygaliby swoje spory w sposób siłowy. Nie potwierdziła się teza, że BICI BIJĄ !

Jednym z filarów Pani działalności jest edukacja dorostych ukierunkowana na tych, którzy profesjonalnie zajmują się wspótpracą z dzieckiem. Czy myślała Pani o włączaniu w zakres edukacji jeszcze innych grup dorosłych, na przykład rodziców?

Tak, wszystkie nasze projekty oraz program rozpoznawania dziecka krzywdzonego, który prowadzimy od ponad siedmiu lat, są nastawione na osoby zawodowo pracujące z dziećmi lub na ich rzecz, na przykład policjanci. Dla nas najskuteczniejszym rozwiązaniem jest to, aby w miejscach, w których są dzieci, były też osoby, które są w stanie rozpoznać ich problem, ich krzywdę, zło, które im wyrządzono.

Doszliśmy do wniosku, że powołanie fundacji dla osób znajdujących się w sytuacji trudnej, które stały się ofiarami przemocy, nie jest wystarczające. Uznaliśmy, że sami nie rozwiążemy wszystkich problemów. Uważamy, że działania muszą mieć charakter systemowy, dlatego włączamy wiele podmiotów prywatnych, instytucji, by wspólnie prowadzić edukację na szeroką skalę.

Założenie jest takie: chcemy naszymi działaniami objąć możliwie jak najszerszą grupę osób. Z jednej strony staramy się dotrzeć do osób, które pracują z dziećmi, czyli są zawodowo $\mathrm{z}$ nimi związane; $\mathrm{z}$ drugiej natomiast od kilku lat prowadzimy debatę społeczną, czyli działalność ukierunkowaną na zmianę mentalności, i włączamy dziennikarzy oraz urzędników. Chcemy w ten sposób uwrażliwiać różne grupy społeczne na sprawy dziecka. Myśleliśmy nawet o przeprowadzeniu sondy ulicznej, aby nauczyć ludzi, w jaki sposób się zachować (co zrobić), gdy w pobliżu znajduje się krzywdzone dziecko.

Niestety, nawet w takim centrum akademickim, jakim jest Kraków, w mieście z tradycjami, do którego zjeżdża cały świat, ludzie takiej wiedzy nie mają i w ogóle nie wiedzą, co zrobić. Nie chcemy ludzi zawstydzać, tylko uświadamiać, ale to jest trudne, więc na razie pozostaje w naszych planach.

W ramach naszej działalności edukacyjnej włączamy się także w tworzenie i zmianę prawa - przesyłamy nasze propozycje, które są wykorzystywane przez różne ministerstwa. Za każdym razem zostawiamy jakieś swoje „okruszki” i z tego bardzo się cieszymy, chociaż wolelibyśmy, żeby było to jednak bardziej skuteczne i żeby nie powstawały takie nieudane zapisy prawne.

2 Trudno zgodzić się z tą tezą Anny Grajcarek, biorąc pod uwagę perspektywę psychologii społecznej i nawiązanie do teorii społecznego uczenia się Bandury czy perspektywę socjologiczną i odniesienie do roli socjalizacji pierwotnej - zjawiska dziedziczenia wzorców przemocy. Przyjmuje się, że fakt doświadczania w dzieciństwie przemocy ze strony rodziców bądź obserwacja przemocy zachodzącej między rodzicami zwiększają prawdopodobieństwo stosowania przemocy wobec dzieci w dorosłości. Większość badań potwierdza, że osoby, które doświadczały przemocy w dzieciństwie, częściej stosują ją w dorosłym życiu. W zależności od metodologii w różnych badaniach stwierdzano, że wśród sprawców przemocy w dzieciństwie doświadczało jej od 20 do 80\% badanych (Herzberger 2003: 97-99). W polskich badaniach z 2001 roku także stwierdzono, że respondenci, którzy sami doświadczali w dzieciństwie krzywdzenia, częściej stosowali je wobec własnych dzieci (Fluderska, Sajkowska 2003) [przyp. aut]. 
I nie jest prawda, że wszyscy jesteśmy równi, bo dzieci sa równiejsze! I to powinno być uwzględnione w ustawodawstwie, bo dzieci nie potrafia się obronić.

Obecnie pracujemy w zakresie edukacji nad skutecznym sposobem trafiania bezpośrednio do dzieci. Myślimy, że taką szansą mogą być szkoły z empatią! Pragniemy z jednej strony, aby był ktoś, kto rozpozna dziecko krzywdzone i będzie wiedział, co z tym zrobić. $Z$ drugiej strony dążymy do tego, by te dzieci były i wobec siebie lepsze, i dla siebie lepsze! Patrząc na dorosłych, wolontariuszy, którzy przygotowują dla nas ewaluację, wierzymy, że można coś zmienić - coś dobrego wykrzesać z ludzi, bez pompy, bez udawania, żeby te dzieci nie musiały grać, że są grzeczne czy dobre! Tylko aby rzeczywiście chciały, aby to było w nich! Muszę powiedzieć, że okrucieństwo dzieci wobec swoich kolegów jest bardzo bolesne i okropne. Spotkaliśmy się z tym problemem w badaniach i rozmowach z dziećmi, które nie chciały chodzić do szkoły.

Wspominała Pani, że jest otwarta na wspótpracę ze studentami pracy socjalnej. Jak wyobraża sobie Pani taka wspótpracę i na czym miałaby ona polegać?

Nasza działalność edukacyjna jest skupiona na różnych odbiorcach, chociaż dotychczas byliśmy nastawieni na nauczycieli, pedagogów, psychologów czy kuratorów. Coraz częściej wśród uczestników naszych projektów trafiamy na pracowników socjalnych. W rozmowach z nimi dowiadujemy się, że brakuje im wiedzy dotyczącej pracy z dzieckiem krzywdzonym. Są tacy, którzy dopiero zaczynają pracować z dziećmi, więc tym bardziej potrzebują profesjonalnego wsparcia. Podam przykład: spotkałam się z taką opinią pracownicy socjalnej, która opowiadała, że dziennikarze potraktowali ją bardzo niesprawiedliwie. Podczas jednej z wizyt w domu rodzinnym, w którym podejrzewano stosowanie przemocy, nie stwierdziła żadnych oznak, które potwierdziłyby podejrzenia. Problem polegał na tym, że wizyta była zapowiedziana, dzieci stały rządkiem, odpowiadały na pytania, bo były przygotowane, lodówka była pełna tylko dlatego, że przyszła, na co dzień dzieci chodziły głodne i większość czasu spędzały na ulicy, nikt się nimi nie zajmował. Wszystko wyglądało normalnie. Nic nie mogła zrobić, mimo że wiedziała, że tam jest przemoc. Musiała zapowiedzieć wizytę, ponieważ taki jest wymóg, takie jest uregulowanie prawne. Żaliła się, że nie mogła rozebrać dziecka. Mogła wezwać lekarza lub policję, nie chciała jednak wywoływać paniki. „Jeśli nie mogę zobaczyć tego dziecka bez ubrania, to skąd mogę wiedzieć, że to dziecko jest bite?” - pytała.

Przykład ten uświadamia nam, że konieczna jest edukacja. Chciałabym, żeby studenci zostali wyposażeni w umiejętności rozpoznawania dziecka krzywdzonego i wiedzieli, jak profesjonalnie zachować się w obecności ofiary oraz sprawcy przemocy. Bardzo ważna jest też umiejętność zidentyfikowania samego sprawcy poprzez wnikliwą obserwację jego zachowania. Często słyszymy, że niedoświadczeni pracownicy socjalni mają trudność w porozumieniu się z członkami rodziny, ponieważ brakuje im asertywności i stanowczości. Nasza fundacja poprzez organizowane warsztaty, spotkania i wykłady zapewnia uczestnikom niezbędną wiedzę w tym zakresie. Uważamy, że wiedza i umiejętności dają poczucie bezpieczeństwa i odwagę do skutecznego działania. 
Uczymy, jak rozpoznać dziecko maltretowane - przedstawiamy objawy fizyczne, różnice między wypadkiem a przemocą wobec dziecka. Szczegółowo dyskutujemy portret psychologiczny dziecka maltretowanego wraz z objawami, które temu towarzyszą. Pokazujemy także portret potencjalnego sprawcy przemocy, który wcale nie musi być agresywny i może robić dobre wrażenie. Dajemy wiedzę prawną, a także psychologiczną. Uczymy, jak rozmawiać z dziećmi krzywdzonymi. Uważamy, że to jest sztuka rozmowy z dzieckiem!

\section{Jakie są Pani marzenia na najbliższa przyszłość?}

Zacznę od tego, że tam, gdzie się pojawiamy, psujemy statystyki, ponieważ zmniejsza się liczba spraw, wzrasta wykrywalność, liczba złożonych Niebieskich Kart. Ale tak całkiem poważnie, chciałabym, aby za dziesięć lat udało nam się uczynić Małopolskę miejscem przyjaznym dla dziecka: z wysoką wykrywalnością przemocy, dobrze rozbudowanym systemem profilaktyki. Każdy, kto będzie wiedział, że za swoje czyny zostanie ukarany, zastanowi się, czy warto podejmować tak ogromne ryzyko. Moim marzeniem jest wyedukowanie grupy nauczycieli, którzy potem mogliby być edukatorami rodziców - uczyliby ich, jak rozładowywać emocje, jak radzić sobie w trudnych sytuacjach itp. Teraz mamy do czynienia z sytuacją, w której dyrektorzy nie przyznają się do problemów, ponieważ chcą, aby ich szkoła miała opinię dobrej. Chodzi o to, aby problemy rozwiązywać, a nie „chować pod dywan”. Te działania są ważne, ale wymagają czasu. Są nastawione na pokolenia...

\section{Refleksje końcowe}

Anna Grajcarek dotyka niezwykle istotnego problemu, jakim jest przemoc, która pojawia się najczęściej w zaciszu domowym za zamkniętymi drzwiami, a sprawcą jest najczęściej najbliższa ofierze osoba. O ile można się zgodzić ze stwierdzeniem, iż dorosła ofiara przemocy domowej może poszukiwać pomocy w instytucjach wsparcia środowiskowego i wystarczy jedynie ten fakt zgłosić odpowiednim organom, o tyle w przypadku dzieci trudno znaleźć obrońców, a one same nie wiedzą, do kogo się zwrócić po taką pomoc czy informację. Z jednej strony czekają na cud, z drugiej natomiast wierzą, iż przemoc fizyczna w postaci klapsa jest elementem wychowawczego programu dorosłych.

Warto podkreślić, że zagadnienie krzywdzenia fizycznego dziecka jest znane $\mathrm{w}$ historii od stuleci. Jednak dopiero w ostatnich latach XIX wieku francuski profesor medycyny sądowej Ambroise Tardieu zajął się wyczerpująco problemem znęcania się nad dziećmi, ze szczególnym uwzględnieniem problemu dziecka maltretowanego. Pierwsze zdjęcie rentgenowskie dziecka maltretowanego wykonane przez Tardieu opublikowano w 1929 roku. Przedstawiało ono kości dwuletniego dziecka cygańskiego, które rodzice bili, żeby zapewnić sobie wysokie dochody z żebractwa (Marciński 2005). Następnie w 1953 roku F.N. Silverman opracował klasyfikację obrażeń fizycznych, jakie dorośli zadają własnym dzieciom. W przygotowanej diagnozie Silverman opisał liczne złamania 
o charakterze patologicznym występujące u niemowląt i nazwał je ,zespołem dziecka bitego" albo „zespołem Silvermana” (Kmiecik-Baran 1998). Współczesne określenie zjawiska znanego w literaturze jako „zespół dziecka maltretowanego” wprowadził amerykański pediatra H. Kemp po drugiej wojnie światowej (Rusin 2002).

W 1970 roku David Gil opracował definicję krzywdzenia dziecka. Według niego krzywdzenie dziecka obejmuje każde działanie lub bezczynność jednostki, instytucji lub społeczeństwa jako całości i każdy rezultat takiego działania lub bezczynności, który deprywuje równe prawa i swobody dzieci i/lub zakłóca ich optymalny rozwój (Gil 1970). Kilka lat później, w 1974 roku, weszła w życie ustawa o zapobieganiu przemocy wobec dzieci i terapii dla dzieci krzywdzonych, natomiast 10 grudnia 1984 roku Zgromadzenie Ogólne Narodów Zjednoczonych przyjęło konwencję w sprawie zakazu stosowania tortur oraz innego okrutnego, nieludzkiego lub poniżającego traktowania albo karania. Zaledwie rok później Światowa Organizacja Zdrowia (WHO) ogłosiła definicję zespołu dziecka maltretowanego, zgodnie z którą ,za maltretowanie dziecka uważa się każde zamierzone lub niezamierzone działanie osoby dorosłej, społeczności lub państwa; działanie, które ujemnie wpływa na zdrowie, rozwój fizyczny i psychospołeczny dziecka" (WHO 2016; Turska i in. 2017). Od wielu lat w celu uświadamiania społecznego organizowane są kampanie społeczne. Tworzone są nowe akty prawne, mające na celu zapewnienie nietykalności dziecku zarówno w wymiarze fizycznym, seksualnym czy psychicznym, jak i obrony jego praw. Powstają podmioty zajmujące się praktyczną stroną powyższych zagadnień.

Takim przykładem jest Fundacja „Ad Vocem”, którą prowadzi Anna Grajcarek. Fundacja aktualnie rozpoczęła kolejną edycję kampanii edukacyjnej pod hasłem: „Mamo, nie krzywdź". Ma ona na celu zapobieganie poważnym wadom rozwojowym, które powstają w życiu płodowym na skutek toksycznego działania alkoholu. Organizatorzy kampanii chcą zwrócić uwagę na to, że picie alkoholu w ciąży może wywołać wiele nieodwracalnych zmian w układzie nerwowym dziecka. Ponadto na rynku wydawniczym pojawiła się książka pod redakcją Anny Grajcarek Jak rozpoznać dziecko krzywdzone? będąca kompendium wiedzy do pracy z dziećmi doświadczającymi przemocy. Co roku fundacja w ramach Funduszu Inicjatyw Obywatelskich prowadzi szkolenia z zakresu pomocy dzieciom pokrzywdzonym, realizując na bieżąco inne cele statutowe.

\section{Bibliografia}

Child Maltreatment (2016). http://www.who.int/mediacentre/factsheets/fs150/en/ (dostęp: 06.12.2018).

Eliminating Corporal Punishment: A Human Rights Imperative for Europe's Children (2005). Rada Europy, Strasbourg.

Fluderska G., Sajkowska M. (2003). Kary fizyczne w dzieciństwie - retrospekcje dorostych Polaków. „Dziecko Krzywdzone”, 3 (3). 
Gil D.G. (1970). Violonce Against Children: Physical Child Abuse in the United States. Harvard University Press, Cambridge.

Herzberger S.D. (2003). Przemoc domowa: perspektywa psychologii społecznej. Państwowa Agencja Rozwiązywania Problemów Alkoholowych, Warszawa.

Kmiecik-Baran K. (1998). Przemoc wobec dzieci - diagnoza i interwencja, w: Przemoc dzieci i młodzieży w perspektywie polskiej transformacji ustrojowej, J. Papież, A. Płukis (red.). Wydawnictwo Adam Marszałek, Toruń: 363-385.

Korczak J. (2002). Jak kochać dziecko. Wydawnictwo Akademickie Żak, Warszawa.

Marciński A. (2005). Dziecko maltretowane - urazy nieprzypadkowe. „Dziecko Krzywdzone. Teoria, Badania, Praktyka", 4 (2): 30-42.

Report of the Consultation on Child Abuse Prevention [Raport z konsultacji w sprawie zapobiegania krzywdzeniu dzieci] (1999). Światowa Organizacja Zdrowia (WHO).

Rusin J. (2002). Medyczne aspekty zespołu dziecka krzywdzonego, w: K. Pikor, W. Walc (red.). Przemoc wobec dzieci. Wybrane zagadnienia teoretyczne i praktyczne, Wydawnictwo UR, Rzeszów.

Turska M., Raban M., Grochowski C., Kulik-Rechberger B. (2017). Child Abuse Syndrome. „Journal of Education, Health and Sport”, 7 (8): 1452-1460.

World Health Organisation (2016). Handbook on developing national action plans to prevent child maltreatment; http://www.euro.who.int/en/publications/abstracts/handbook-ondeveloping-national-action-plans-to-prevent-child-maltreatment-2016 (dostęp: 12.12.2018). 